Proceedings

\title{
Study of Natural Hazards in the Upper Part of the Mapocho River Basin, Metropolitan Region of Chile, Using Satellite Imagery ${ }^{\dagger}$
}

\author{
Waldo Pérez-Martínez ${ }^{1,2, *}$, Josep E. Pardo-Pascual ${ }^{2}$, Idania Briceño ${ }^{1,2}$ and Paulina Vidal 1,2 \\ 1 Hémera Centro de Observación de la Tierra, Facultad de Ciencias, Universidad Mayor, \\ Santiago 8340589, Chile \\ 2 Departamento de Ingeniería Cartográfica, Geodesia y Fotogrametría, Universitat Politècnica de València, \\ 46022 Valencia, Spain \\ * Correspondence: waldo.perez@umayor.cl; Tel.: +56-22-3281220 \\ † Presented at the II Congress in Geomatics Engineering, Madrid, Spain, 26-27 June 2019.
}

Published: 12 July 2019

\begin{abstract}
The upper section of the Mapocho river basin is in constant danger of landslides. This study had the objective of zoning the upper Mapocho river basin for the susceptibility of landslides using hydrological, geological, and geomorphological data. Areas with a high degree of landslide susceptibility are located on the lower part of the main valleys as well as at the headwaters of the basins. Landslide events in the mountainous region of Central Chile are caused by two main factors: intense precipitation and seismic activity.
\end{abstract}

Keywords: susceptibility; landslides; Mapocho river basin

\section{Introduction}

The Central Andes range of Chile is geologically characterized by the presence of stratified, sedimentary, volcanic, and volcanoclastic rocks that date from between the Eocene and middle Miocene [1]. Among the most essential structural traits are the North to South Olivares River Fault, to the west the Dominion of the Abanico basin and, to the East, the Dominion of the Faja Plegada and Corrida of Aconcagua [2,3]. Geomorphological dynamics of the central region of Chile are subject to tectonic (i.e., orogenesis), climatic (i.e., differential erosion), and volcanic processes. These processes are relief shaping agents characterized by their considerable dynamism due to their periglacial morphoclimatic position [4]. The geomorphological systems present in the upper part of the Mapocho river basin have been formed from endogenous and exogenous processes that are permanently active within and among the systems and in response to the combined action of meteorological and seismic variables [5]. The objective of this research study was gathering, systemizing, and analyzing raw data through the use of satellite images, aerial photographs, MDE and topographic maps of the geological, geomorphological, and hydrological components. This compilation of data made it possible to identify and zone the areas which are most susceptible to landslides in the upper Mapocho river basin.

\section{Materials and Methods}

\subsection{Study Area}

This study was carried out in the hydrographic sub-basins of the San Francisco, Molina and Olivares Rivers, which are located along the upper section of the Mapocho river basin in the Central Chilean Andes, $30 \mathrm{~km}$ northeast of the country's capital city, Santiago. This area lies between the 
coordinates: latitude $33^{\circ} 03^{\prime}-33^{\circ} 29^{\prime}$ South and longitude $70^{\circ} 06^{\prime}-70^{\circ} 23^{\prime}$ West (Figure 1). Administratively, this zone covers the municipalities of Lo Barnechea and San José de Maipo, which are within the Santiago Province, Metropolitan Region, and has a total surface area of $1139 \mathrm{~km}^{2}$.

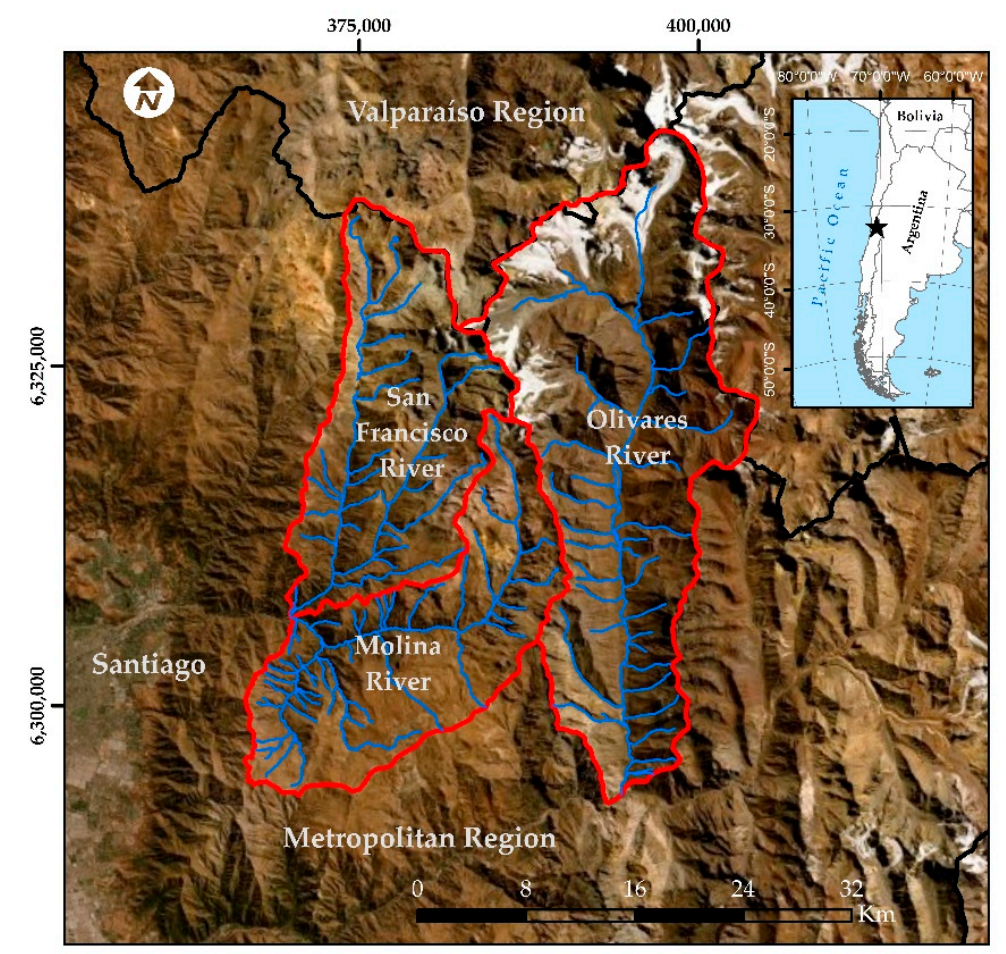

Figure 1. Location of the sub-basins of the San Francisco, Molina and Olivares rivers in the upper section of the Mapocho river basin.

\subsection{Data Sources \& Remote Sensing}

A bibliographic review of components of hydrography, geology, and geomorphology was carried out. In visual interpretation was used: (a) mosaic of high resolution images of the Pleiades satellites at a resolution of $50 \mathrm{~cm}$; (b) topographic maps of the Metropolitan Region, section E, digital cartography at a scale of 1:50,000; (c) analogous aerial photographs of the Hycon flight at a scale of 1:70,000 and (d) interferometric DEM ALOS PALSAR at a resolution of $12.5 \mathrm{~m}$.

\subsection{Visual Interpretation \& Field Survey}

The visual interpretation of the geological, geomorphological and hydrological attributes was made using the photo-interpretation of the mosaic of satellite images, which was supported by aerial photographs, topographic cartography and an interferometric digital elevation model (DEM). Also, nine field studies were conducted, with a total of 42 effective days of work, and these field studies were carried out in the sectors of Farellones-Valle Nevado, Yerba Loca, El Cepo, Olivares and San Francisco rivers.

\subsection{Susceptibility Index}

Susceptibility to landslides was evaluated using the susceptibility index (SI) proposed by Lara [6] and updated by Lara and Sepúlveda [7]. This index is calculated for each defined unit of land and is based on the sum of weighted scores for each of the conditioning factors of landslides (Equation (1)).

$$
\mathrm{SI}=\sum_{i=0}^{6} f_{i} * \text { map } \text { factor }_{i}
$$

where $f_{i}$ corresponds to the sum of the weighted ratings (ranging from 1 to 5 ) assigned to base maps reclassified using GIS and mapfactor ${ }_{i}$ corresponds to the percentage assigned (ranging from $5 \%$ to 
$40 \%$ ) to each reclassified map according to its importance in generating landslides (Table 1). The software program $\mathrm{ArcGis}^{\circledR}$ was used to process the acquired data, create new data, reclassify base maps, and perform the calculation of the susceptibility index by using the tool Raster Calculator.

Table 1. Weighting of conditioning factors for landslides.

\begin{tabular}{ccc}
\hline Factor & Weight $^{1}$ & Percent \\
\hline Slope $\left(f_{1}\right)$ & $1,2,3,4,5$ & $25 \%$ \\
Sun exposure $\left(f_{2}\right)$ & $1,2,3$ & $5 \%$ \\
Geology $\left(f_{3}\right)$ & $1,2,3,4,5$ & $40 \%$ \\
Distance to geologic fault $\left(f_{4}\right)$ & $0,1,2,3,4$ & $10 \%$ \\
Distance to hydrographic network $\left(f_{5}\right)$ & $1,2,3,4,5$ & $10 \%$ \\
Hydrographic density $\left(f_{6}\right)$ & $1,3,5$ & $10 \%$ \\
\hline${ }^{1}$ Weight 0 = Null; 1 = Very low; 2 = Low; $3=$ Moderate; 4 = High; $5=$ Very high.
\end{tabular}

The susceptibility index was evaluated and assigned according to each conditioning factor $\left(f_{i}\right)$ and the class of each factor, which varied between 0 and 5 (Table 2).

Table 2. Index values and the degree of susceptibility to landslides.

\begin{tabular}{|c|c|}
\hline Susceptibility Index & Degree of Susceptibility \\
\hline$>2$ & Low \\
\hline $2-3$ & Moderate \\
\hline $3^{1}-5$ & High \\
\hline
\end{tabular}

\section{Results and Discussion}

The 93 landslides events included in the inventory were concentrated in the rivers Yerba Loca, El Cepo and San Francisco. Five types of landslides deposits were recognized: debris flow, debris flood, rock fall, rock avalanche and slides. The susceptibility analysis indicated that more than $80 \%$ of the area under study were zones of low to moderate risk (Table 3). On the other hand, high risk areas (i.e., $16 \%$ of the surface area) were mainly concentrated in the bottoms of valleys and the unstable regions near valley headwaters. The sub-basin of the Molina river had the largest area of low risk zones and the sub-basins of the San Francisco and Olivares rivers contained the areas of greatest risk (Figure 2).

Table 3. Surface area and percentage by degree of susceptibility to landslides.

\begin{tabular}{cccc}
\hline Range & Degree & Surface Area $\left.\mathbf{( K m}^{2}\right)$ & Percent \\
\hline $0.9-2.25$ & Low & 352.05 & $30.89 \%$ \\
$2.25-3.51$ & Moderate & 598.57 & $52.52 \%$ \\
$3.51-4.6$ & High & 189.01 & $16.59 \%$ \\
\hline
\end{tabular}

The upper sector of the Mapocho River basin, according to historical records from the past 100 years, is highly vulnerable to meteorological and climactic changes, which, if projections are maintained on a global scale, could increase the incidence of landslides events while also increasing their magnitude and their destructive power. In this sense, the impact of relief shaping agents on the sub-basins, which are currently in a stage of morphoclimatic transition and the active margin of two tectonic plates, will likely be greater in the present and near future. 


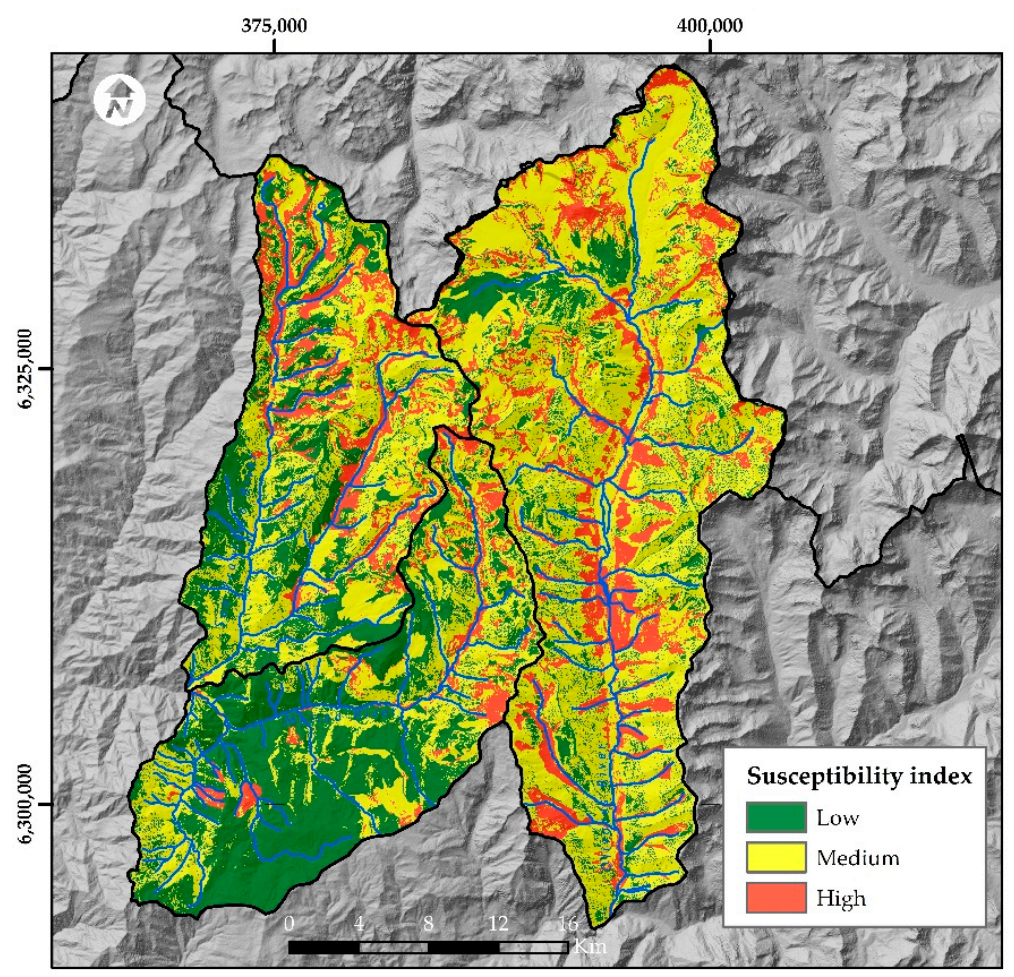

Figure 2. Susceptibility map to landslide in the upper sector of the Mapocho river basin.

\section{Conclusions}

The analysis established that tectogenesis and climatic changes following the Pleistocene era have triggered the development of various morphogenetic processes that have been identified and associated with systems glacial, gravitational, alluvial and fluvial. The changes in the morphology of the sub-basins are evolutionary in nature. From the post-glacial period to the present, they have undergone an accelerated transformation from glacial to fluvial basins. Through the creation of an inventory of landslides (93), at least five types of geologically active deposits were recognized in the area: debris flow, debris flood, rock avalanche, rock fall and slides. The two main and most common types of geologically active deposits were floods and debris flows. In the zoning of susceptibility to landslides, the zones of low, medium, and high susceptibility corresponded to $31 \%, 53 \%$ and $16 \%$ of the total surface of the area under study. Areas with a high degree of susceptibility to landslides were located in the upper parts of the main valleys, as well as in downstream areas. This is consistent with the main types of landslides deposits recognized on the ground. For the most part, these corresponded to water flows (with different concentrations of debris and water), meaning that their mobility is essentially conditioned by topography.

Author Contributions: Conceptualization, W.P.-M.; methodology, W.P.-M., I.B. and P.V.; software, W.P.-M.; validation, W.P.-M., I.B. and P.V.; formal analysis, W.P.-M.; investigation, W.P.-M.; resources, W.P.-M.; writing - original draft preparation, W.P.-M.; writing - review and editing, W.P.-M. and J.E.P.-P.; visualization, W.P.-M.; supervision, J.E.P.-P., I.B. and P.V.

Funding: This research was funded by Hémera Centro de Observación de la Tierra of Universidad Mayor.

Acknowledgments: This study was supported by the Hémera Centro de Observación de la Tierra of Universidad Mayor, geologist Jorge Clavero and Bárbara Droguett, and is part of the doctoral thesis in Geomatics Engineering for the Universitat Politècnica in València, Spain.

Conflicts of Interest: The authors declare no conflict of interest. 


\section{References}

1. Muñoz-Sáez, C.; Pinto, L.; Charrier, R.; Nalpas, T. Influence of depositional load on the development of a shortcut fault system during the inversion of an extensional basin: The Eocene-Oligocene Abanico Basin case, central Chile Andes (33-35 S). Andean Geol. 2013, 41, 1-28, doi:10.5027/andgeoV41n1-a01.

2. Charrier, R.; Bustamante, M.; Comte, D.; Elgueta, E.; Flynn, J.; Iturra, I.; Muñoz, N.; Pardo, M.; Thiele, R.; Wyss, A. The Abanico extensional basin: Regional extension, chronology of tectonic inversion and relation to shallow seismic activity and Andean uplift. Neues Jahrb Geol Paläontol.-Abh. 2005, 236, 43-77, doi:10.1127/njgpa/236/2005/43.

3. Piquer, J.; Skarmeta, J.; Cooke, D.R. Structural Evolution of the Rio Blanco-Los Bronces District, Andes of Central Chile: Controls on Stratigraphy, Magmatism, and Mineralization. Econ. Geol. 2015, 110, 1995-2023, doi:10.2113/econgeo.110.8.1995.

4. Araya Vergara, J. Geomorfología glacial y periglacial en la cuenca andina del Mapocho, Andes de Santiago. Investig. Geogr. 2008, 40, 21-48.

5. Araya Vergara, J. Primeras experiencias con una clasificación dinámica de vertientes de montaña. In I Taller Internacional de Geoecología de Montaña y Desarrollo Sustentable de los Andes del Sur; Universidad de ChileUnicef-The United Nations University: Santiago, Chile, 1996; pp. 389-399.

6. Lara, M. Metodología Para la Evaluación y Zonificación de Peligro de Remociones en Masa Con Aplicación en Quebrada San Ramón, Santiago Oriente, Región Metropolitana. (Methodology for Landslide Hazard Assessment and Zoning with Application in San Ramón Ravine, Eastern Santiago, Región Metropolitana). Master's Thesis, University of Chile, Santiago, Chile, 2007.

7. Lara, M.; Sepúlveda, S.A. Landslide susceptibility and hazard assessment in San Ramón Ravine, Santiago de Chile, from an engineering geological approach. Environ. Earth Sci. 2010, 60, 1227-1243, doi:10.1007/s12665-009-0264-5.

(C) 2019 by the authors. Licensee MDPI, Basel, Switzerland. This article is an open access article distributed under the terms and conditions of the Creative Commons Attribution (CC BY) license (http://creativecommons.org/licenses/by/4.0/). 